\title{
Территориальные проблемы
}

\section{МЕЖИУНАРОДНО-ПРАВОВОЙ СТАТУС РНБООХРАННОЙ ЗОНЫ ВОКРУГ ШШИЩБЕРГЕНА}

А.К. Криворотов *

В середине 70-x годов в политике Норвегии в определенных: областях произошли серьезные изменения. По примеру других континентальных государств Норвегия с 1 января 1977 г. установила у своего побережья 200-мильную исключительую экономическую зону, на севере простирающуюся далеко в Баренцево море. В это же время началась активизащия политико-дипломатической деятельности страны в отношении архипелага ІІпицберген (норвежское название - Свальбард). Основу этому процессу, продолжающемуся по сей день, заложил представленный в 1975 году систематизированный правительственный доклад "Относительно Свальбарда".

Следствием интереса Норвегии $к$ архипелагу стало создание в июне 1977 года вокруг ІІпицбергена 200-мильной рыбоохраннойі зоны. Анализ ее юридического статуса, практики реального функционирования и роли зоны во внешней политике Норвегии, включая: двусторонние отношения с Россией, и составляет предмет настоящего исследования.

\section{Границы и статус рыбоохранной зоны}

Рыбоохранная зона вокруг Шпицбергена учреждена Королевской резолюцией от 3 июня 1977 г. на основании Закона об экономической зоне Норвегии 1976 года.

Согласно $\S 1$ резолюции, рыбоохранная зона простирается на. 200 морских миль от исходных линий архипелага (а если таковые не установлены, то от линий, соединяющих его крайние точки). С юга она ограничена внешней границей экономической зоны Норвегии. Установлено, что в случае соприкосновения зоны с районами

* Специалист-эксперт Отдела межпарламентских связей Государственной Думы Федерального Собрания Российской Федерации. 
юрисдикции другого государства "граница будет определена договорным путем". Часть этой границы проведена по срединным линиям между Шпицбергеном и, соответственно, Гренландией, Землей Франца-Иосифа и Новой Землей. Рыбоохранная зона ІІпицбергена имеет, таким образом, довольно сложную конфигурацию (см. схему).

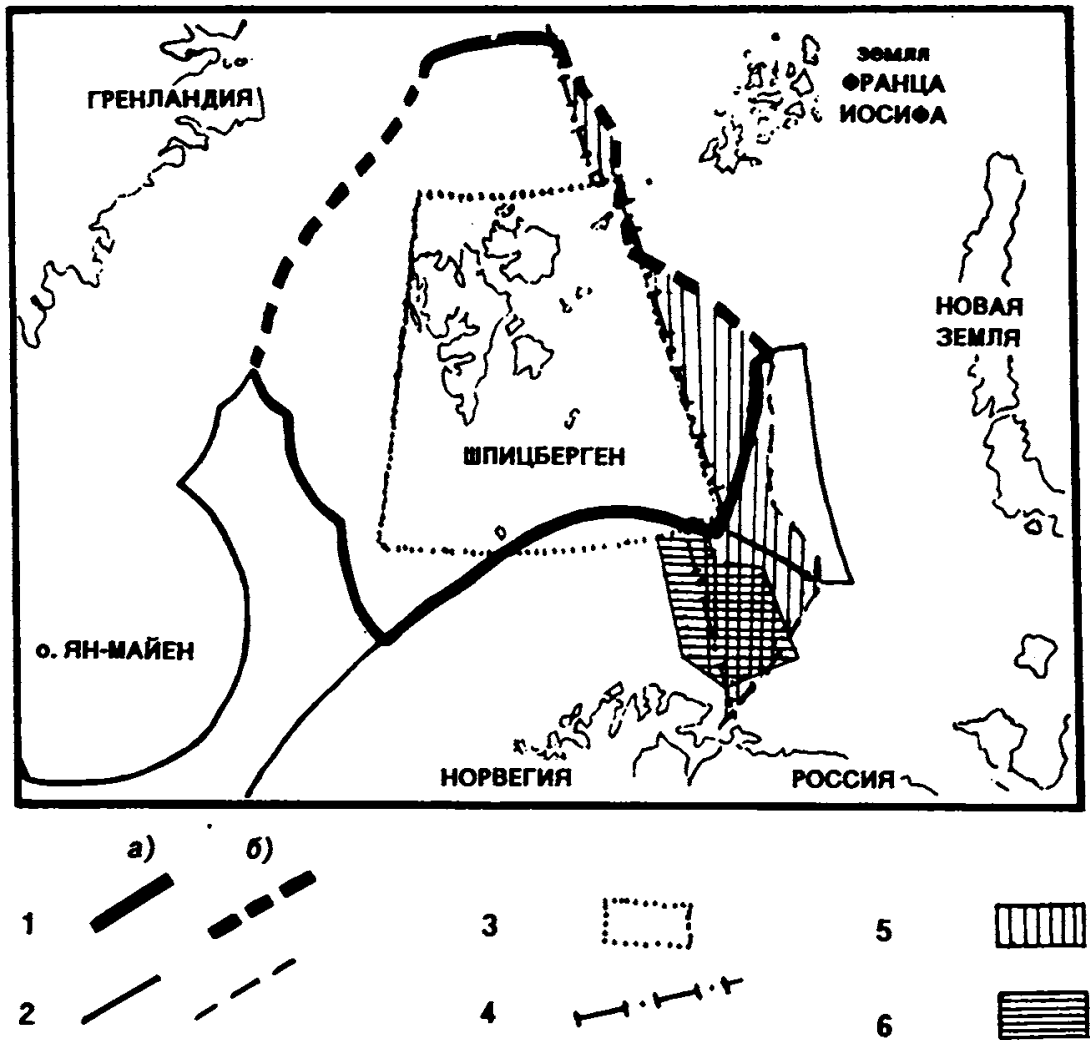

Рыбоохранная зона вокруг ШІпицбергена и другие морские территории в Северной Атлантике:

1 - границы рыбоохранной зоны; 2 - иные морские границы: а) 200-мильные, б) проведенные по срединным линиям; 3 - зона действия Договора о ІІпицбергене 1920 года ("шпицбергенский квадрат"); 4 - секторная линия разграничения; 5 - спорный участок Баренцева 
моря; 6 - смежный участок рыболовства между Россией и Норвегией ("серая зона").

Составлено по: NOU 1989:9. Norsk polarforskning. S. 22; Unitemt. 1988. - Nr. 2. - S. 25.

Министерство рыболовства Норвегии получило в соответствии c $\$ 3$ резолюции право устанавливать сезонные и круглогодичные запреты на промысел в отдельных районах зоны, принимать меры по регулированию орудий лова, определять минимальные размеры вылавливаемой рыбы и предельно допустимые уловы каждого вида рыб. На суда, ведушие в зоне промысел, были возложены обязанности еженедельо предоставлять в Директорат рыболовства Норвегии сводки улова (\$ 4) и оказывать содействие проведению инспекщий (§ 5). За нарушение этих правил предусмотрены штрафы (§ 6). Формулировки резолюции носят намеренно недискриминационный характер, не предоставляя норвежским рыбакам каких-либо особьх привилегий.

Отдельные вопросы рыболовства в зоне были конкретизированы В последуюших документах. В частности, В 1979 году на основании резолюции были приняты Предписания по рыболовству в рыбоохранной зоне вокруг IIпицбергена, в которых содержатся требования $к$ орудиям лова, а также устанавливается запрет на промысел в районе острова Медвежий и у западного побережья острова Шпицберген ${ }^{1}$. В 1990 году был запрещен промысел морского гребешка вблизи осгровов Медвежий и Моффен. Начиная с 1986 года ежегодно принимаются Предписания по регулированию в зоне вылова норвежской арктической трески. В них определяются сроки, квоты и порядок промысла. Норвегия при этом исхопит из своей национальной квоты и квоты третъих стран в Баренцевом море, устанавливаемых Норвегией и Россией (ранее СССР) на ежегодных сессиях смешанной комиссии по рыболовству.

Контроль за соблюдением норвежских правил лова в рыбоохранной зоне возложен на Береговую охрану (БОХР) - особую службу, вХодящую в состав Вооруженных сил Норвегии и финансируемую из бюджета Министерства обороны, но в мирное время фактически подчиненную Министерству юстиции. Патрулирование в рыбоохранной зоне ІІпицбергена, равно как и в экономической зоне Норвегии севернее $62^{\circ}$ с.ш. и в рыболовной зоне вокруг острова Ян-Майен, выполняют корабли эскадры БОХР "Север". Фрегаты Береговой охраны - самые крупные боевые корабли в Норвегии, обладающие "ледовым классом", необходимым для длительного плавания в арктических морях.

Хозяйственное значение зоны определяется тем, что она охватывает обширные пространства, имеюшие важное значение для восп- 
роизводства мойвы, трески и других промысловых рыб. На район UInицбергена приходится также до $40 \%$ ежегодного улова креветки в северо-восточной Атлантике 2 .

\section{Правовые в политические проблемы}

Норвежцы не скрывают, что причиной учреждения именно рыбоохранной, а не исключитељной, зоны явился не до конца урегулированный правовой статус ШІпицбергена и омывающих его вод. Как известно, Норвегия получила архипелаг в соответствии с Договором о Шипицбергене, подписанным 9 февраля 1920 г. в Париже ${ }^{3}$. Договор признал "полный и абсолютный суверенитет" Норвегии над островами (ст. 1), но установил ряд принципиальных изъятий, делающих IIпицберген уникальным объектом международного права. В частности, подданные любой страны - участницы Парижского договора (СССР присоединился к договору в 1935 г.) имеют право беспрепятственно проникать на архипелаг, заниматься там различной хозяйственной деятельностью, пользоваться станциями беспроволочного телеграфа и др. (ст. 2-4). Норвегия может принимать необходимые природоохранные меры (ст. 2), но они, равно как и налоговый, имущественный, горнопромышленный режимы, должны распространяться на всех лиц без изъятий или привилегий (ст. $2,7,8$ ).

До сих пор ведутся дискуссии о правовом режиме Шпицбергена. Так, практически до конца 80-х годов бывший Советский Союз отрицал возможность какого-либо воздействия Норвегии на свою деятельность на архипелаге под предлогом "экстерриториальности" советских поселков. В начале 60-х годов острые споры возникли с компаниями ряда стран (прежде всего СШІА и СССР) по поводу регулирования нефтегазопоисковых работ. Различным образом подходят страны и к трактовке статьи 9 договора, устанавливающей демилитаризованный статус архипелага.

Не урегулирован также режим вод Шпицбергена. Формально Парижский договор распространяется лишь на сухопутные пространства и четырехмильные территориальные воды архипелага, к которому отнесены все большие и малые острова и скалы, расположенные между $74^{\circ}$ и $81^{\circ}$ с.ш. и между $10^{\circ}$ и $35^{\circ}$ в.д. (ст. 1). Статус водных пространств в этом так называемом "шпицбергенском квадрате" за пределами четырех миль договор не устанавливает. Это вполне объяснимо, поскольку в 1920 году понятия "исключительная экономическая зона", "континентальный шельф" и подобные в международном праве отсутствовали.

Согласно позиции Норвегии, установленные договором ограничения суверенитета распространяются лишь на сам архипелаг и четы- 
рехмильную зону. Морские пространства за ее пределами - это воды, омывающие норвежскую территорию, в которых страна может самостоятельно регулировать экономическую деятельность на общих основаниях. Парижский договор, таким образом, трактуется, буквально, в соответствии с его дословным содержанием. Норвежцы при этом ссылаются на международную практику толкования договоров, В соответствии с которой ограничения национального суверенитета не принято трактовать расширительно. Такой попход подробно обосновывается, например, в упомянутом правитељственном докладе "Относительно Свальбарда"4 и подтвержден в аналогичном документе, представленном десять лет спустя 5 .

В соответствии со своими принципиальными установками норвежская сторона постоянно подчеркивает, что вправе установить вокруг Шпицбергена исключительную экономзону, как и у континентального побережья. "Однако, - указывается в статье норвежского министра иностранных дел, написанной специально для опубликования в СССР, - с тем, чтобы избежать противоречий в толковании договора, что могло бы осложнить практические усилия по сохранению запасов рыбы в этом районе, Норвегия пока ограничилась установлением недискриминационной зоны"“. Вместе с тем страна не отрицает возможности ужесточения в дальнейшем режима рыболовства в зоне.

Норвежская точка зрения на статус вод ІІпицбергена не получила, однако, международной поддержки. С официальным признанием зоны выступила лишь Финляндия, не имеющая в зоне Шпицбергена экономических интересов ни сейчас, ни в обозримом будущем. Другие крупные государства (СІІА, ФРГ, Великобритания и др.) зарезервировали позиции, то есть не выступили официально ни за, ни против создания зоны, сохранив за собой право сделать это в дальнейшем.

СССР выступил против этого акта норвежской стороны. В ноте Посольства СССР в Норвегии от 15 июня 1977 г. подчеркивалось: "Советское правительство расценивает принятое 3 июня 1977 года решение как очередной шаг Норвегии, направленный на незаконное расширение своих прав в районе Шпицбергена вопреки положениям Договора 1920 года, что выходит за рамки чисто рыболовных проблем". Аналогичные формулировки содержатся и в академической "Истории Норвегии"7. В последующих дипломатических документах отмечено, что духу и целям Парижского договора соответствовало бы распространение лрав его участников и на воды Іпицбергена. При этом, в частности, делается ссылка на используемый ООН принцип, согласно которому право на море определяется правом на сушу. Анализируя ситуацию, английский ученый Р. Черчилль писал: "В общей сложности эти аргументы выглядят сильнее норвежских, но, 
пожалуй, не являются полностью убедительвми. В любом стучае данный спор едва ли будет разрешен на основании чисто юридической аргументации" 8 . В этой связи представляется целесообразным проанализировать имеющуюся практику функшионирования рыбоохранной зоны, включая внешнеполитическую активность заинтересованных государств.

\section{Практнческие проблемы контроля за ркболовством в зоне}

Несмотря на официаљное непризнание статуса рыбоохранной зоны, большинство стран длительное время в основном соблюдали его de facto. Они соглашались с полномочиями Норвегии по управлению биоресурсами в районе Шпицбергена, но подчеркивали, что принимаемые меры не должны носить дискриминаиионного характера. Такая политика, очевидно, была во многом связана с резким свертыванием самого промысла в резултате сокращения рыбных ресурсов. Если в течение десятилетия до установления зоны ежегодный вылов трески в районе їпицбергена составлял около 150 тыс.т, то в конце 70-х годов он колебался в пределах от 8 до 20 тыс. т. Промысел стран ЕС (тогда "десятки") находился на минимаљьом уровне. Единственной страной, которая в тот период ңәращивала свои уловы в этом районе, была Испания (примерно с 4 до 10 тыс. т, что существенно превышало норвежские рекомендация). Норвегия предприняла в этой связи ряд интенсивных дипломатических шагов, однако убедить испанцев в необходимости прекратить бесконтрољьный вылов ей не удалось'.

Советское руководство, заявив о непризнании зоны, приняло соответствуюшие меры и внутри страны. Капитанам судов, ведуших промысел в Баренцевом море, была направлена раднограмма с указанием Министерства рыбного хозяйства: "Промысел рыбы для ндших судов запрещается только во внутренних и территориаљьых водах островов Шпицбергена, Медвежьего. Ширина тервод четыре мили. В остальном районе промысел без ограничений в соответствии с Договором 1920 года с безусловным соблодением правил рыболовства"10.

Советские рыбаки следовали данным указаниям. Они не предоставляли норвежским властям рапортов о промысле (за что норвежцы регулярно делали им предупреждения) и не подписывали протоколов инспекций БОХР. При увеличени норвежцами ширины ячеи в рыбоохранной зоне советские суда продолжали вести лов в соответствии со своими нащиональньми требованиями. В то же время представители органов норвежского рыбнадзора на борт наших су- 
дов допускались беспрепятственно и улов не скрывался. Советские суда, как правило, выполняли (хотя и с периодическими задержками) указания норвежцев по выходу из участков зоны, особо богатых рыбной молодыю. Норвежские рыбаки и ученые отмечали не без недовольства, что Советский Союз пользуется в районе IIпицбергена несколько особым статусом ${ }^{11}$, но в целом там сохранялась достаточно спокойная и мирная обстановка. Придерживаясь принципиально различных точек зрения по рыбоохранной зоне, стороны на практике стремились избегать конфронтации ${ }^{12}$.

Однако со второй половины 80-х годов в зоне регулярно возникают острые конфликты межпу Береговой охраной и рыбаками иностранных государств. Первый из них разгорелся в июле 1986 года, когда у побережья IІпицбергена были обнаружены 37 траулеров под флагами ФРГ, Великобритании, Португалии, Испании, ГДР и Гренланпии. Под предлогом обеспечения сохранности трескового стада впервые в истории зоны норвежское правительство потребовало приостановки с 30 июля 1986 г. промысла арктической трески судами всех стран, кроме СССР и Норвегии. Этому указанию подчинились все государства за исключением Испании.

Испания именовала пространства вокруг IIпицбергена международными водами, не подпадающими под норвежскуюо юриспикщию13. Испанское правительство сообщило также, что оно дало разрешение на возобновление промысла судам своей страны (в зоне их на тот момент было восемь плюс еще четьре - в режиме ожидания в порту Тромсе). Норвежцы пригрозили в этом случае арестовать траулеры. Испанщы резко протестовали, но 13 августа все же вывели суда из зоны, не приступив к промыслу. Насколько можно судить, такое решение было принято самими судовладельцами, опасавшимися норвежских штрафов. Испанские рыбаки требовали в качестве ответной меры установить бойкот норвежских рыбопродуктов на своем рынке, а также провести по вопросу о зоне специальную конференцию с представительством всех стран-участниц Договора о IIпицбергене ${ }^{14}$.

Следующее обострение ситуашии произошло летом 1988 года. В рыбоохранной зоне ІІпицбергена было тогда обнаружено свыше 20 испанских траулеров, ведущих промысел с нарушением норвежских правил лова (прилов молоди составлял до 40\%, а примерно 760 т рыбы испанцы пытались скрыть от досмотра). Норвежские власти, несмотря на требования общественности, не стали арестовывать траулеры. Конфликт был урегулирован по дипломатическим каналам, включая прямой контакт министров иностранных дел двух стран. Испанское правительство, насколько можно судить, сообщило своим траулерам, что не будет оказывать им своей поддержки в 
случае продолжения такого промысла. Вскоре суда покинули зону, исчерпав, впрочем, к тому времени свои квоты ${ }^{15}$.

В мае 1991 года конфликт произошел из-за появления в зоне гренландского траулера "Полар Принцесс". Орган местного самоуправления Гренландии, имеющий широкие автономные права, дал офипиальное разрешение на промысел. В ответ на возможные штрафные меры Норвегии предполагалось запретить норвежцам весьма важный для них промысел креветки в водах Гренландии (около 2500 т ежегодно). "Полар Принцесс" выловил 1 тыс.т трески, и норвежцы, несмотря на имевшиеся у них возражения, не стали этому препятствовать. Проблема была урегулирована путем компромисса: по договоренности от 20 июня 1991 г. гренландцы получили право на вылов в течение двух лет $1300 \tau$ трески в норвежской экономической зоне в обмен на обещание не возобновлять промысел в рыбоохранной зоне.

Однако сложности на том не прекратились. "Полар Принцесс", а затем и другие гренландские траулеры приступили к лову в своеобразном "кармане" - в спорном участке Баренцева моря, находящемся за пределами советской и норвежской 200-мильных зон. Годом ранее там вели промысел фарерцы, но свернули его после норвежской угрозы соответственно "срезать" их квоты в экономзоне Норвегии. Гренландские суда еще неоднократно появлялись в рыбоохранной зоне (наиболее активно - в середине сентября). По норвежским оценкам, неконтролируемый вылов трески третьими странами в зоне ІШпицбергена, в "кармане" и в советской зоне составил около 30 тыс. $T$ при общедопустимом улове в тот год в размеpe 240 тыс. $T^{16}$.

Для урегулирования ситуашии 19 сентября 1991 г. на Гренландию вылетела делегация МИД Норвегии. После недели интенсивных переговоров было подписано двустороннее соглашение о сбалансированном взаимном предоставлении квот на 1991-1992 годы, включавшее, в частности, обязательство гренландцев не вести промысел в рыбоохранной зоне. В обмен на это они получили право вылова $3830 \tau$ трески и других рыб в экономзоне Норвегии, преимущественно в ее южном секторе (Северное море до $62^{\circ}$ с.ш.). Лишь тогда гренландские власти приказали своим траулерам покинуть рыбоохранную зону ${ }^{17}$. Норвежцы, судя по всему, придавали урегулированию этого вопроса большое политическое значение. Министр иностранных дел Т. Столтенберг из-за конфликта с Гренландией отменил даже визит в $\mathrm{OOH}^{18}$.

Конфликтные ситуащии (начиная с 1988 г.) выявили некоторую нерешитељность норвежцев. Они не прибегают в зоне ІІпицбергена к силе или угрозе силой (как это делали, например, исландцы и 
англичане в ходе знаменитых "тресковых войн"), не подвергают суда-нарушители задержанию, а предпочитакот решать все вопросы по дипломатическим каналам. Отвечая в конце 1991 года на прямой депутатский запрос об ужесточении контроля в зоне, О. Петтерсен, в то время министр рыболовства, не назвала никаких конкретных мер $^{19}$. Норвежская пресса писала, что у БОХР имеется секретная инструкщия не задерживать иностранные суда в рыбоохранной зоне. В этой связи характерно признание комантира эскадры "Север" капитана II ранга А. Клепсвика: "Если бы такая ситуаџия возникла в норвежской экономической зоне, суда принудили бы к заходу в норвежский порт с предъявлением обвинения в незаконном промысле. Поскольку же этот промысел ведется в рыбоохранной зоне, где имеется ряд неурегулированных юридических вопросов, нами применяется единственная формя реакции - письменное предупреждение"20. Известную роль играли и внешнеполитические соображения: Норвегия, безусловно, не желала вооруженных столкновений со своим партнером по НАТО, тем более в районе, где у нее имелся ряд неурегулированных вопросов с бывшим СССР ${ }^{21}$.

Такая линия, однако, не пољзуется поддержкой внутри страны. Норвежские рыбаки не без основания сетуют на свое правительсто, которое запрещает им вести промысел в рыбоохранной зоне, а иностранцам реальо не препятствует. В результате, по их мнению, норвежские меры регулирования фактически оборачивағотся против наџионального рыболовства. По этим соображениям рыбаки, а также представители экологических партий и течений требовали от правительста более энергичных мер, включая предоставление Береговой охране права на задержание иностранных траулеров без дополнительных согласований. Такое право охрана получила лишь в конце 80-х годов и лишь в пределах четырехмильных территориальных вод. В 1991 году наиболее решительные норвежские рыбаки приступили в рыбоохранной зоне к промыслу синекорого палтуса с нарушением установленных правил, поставив собственное правительство в особо щекотливое положение.

Это давление внутри страны необходимо принимать во внимание. Со временем оно, очевидно, будет возрастать и может привести к практическим результатам, тем более что общая линия Норвегии в отношении ІІпицбергена строится именно на постепенном расширении своей юрисдикции. Кроме того, политическое значение рыбоохранной зоны не ограничивается чисто рыболовными интересами, а связано с решением ряда важных международных вопросов. 


\section{Рыбоохранная зона Ifтицергена и другие территориальие проблемы на Севере}

Восточный сегмент рыбоохранной зоны, выходящий за пределы "шпицбергенского квадрата", расположен в так называемом спорном участке Баренцева моря - территории общей площадью около 155 тыс. кв. Км, которую оспаривают Россия (ранее СССР) и Норвегия. Разграничение морских пространств Баренцева моря самостоятельный и весьма сложный вопрос; отметим лишь, что соответствующие переговоры ведутся уже около 20 лет и близки к завершению. Согласно Королевской резолюции 1977 года, со вступлением в силу соответствующего договора граница рыбоохранной зоны будет изменена и на востоке пройдет по линии разграничения. Это изменение, впрочем, будет носить в основном формальный характер. На российскую позицию по зоне оно самостоятельного влияния не окажет, а промысел в этом участке, насколько можно судить, не очень масштабен.

Рыбоохранная зона непосредственно связана с еще одной важной проблемой - статусом шельфа в районе "шпицбергенского квадрата". Основной вопрос здесь тот же, что и в случае самой зоны: норвежский суверенитет распространяется на шельф архипелага полностью или же с ограничениями, установленными Парижским договором? Принять первую точку зрения, за которую активно выступает Норвегия, означает распространитъ на шель Ф Шпицбергена норвежское нефтяное законодательство, одно из наиболее жестких в мире. Вторая же позиция влечет за собой практически свободный доступ к этому шельфу компаний всех стран-участниц Договора 1920 года. Ее в свое время (примерно по 1988 г.) активно отстаивал СССР, предлагая разработать соответствующие международные правила, а на переходный период пользоваться Горным уставом Шиицбергена 1925 года с его явочным поряпком проведения работ по изысканию и добыче полезных ископаемых. Подходы остальных стран по данному вопросу полностью совпадают с их подходами к рыбоохранной зоне.

В настоящее время проблема шельфа IIпицбергена приобретает практическое значение. Деятельность нефтяных компаний Норвегия все более смещается на север. Так, в 1989 году решением Стортинга был открыт для разработок участок шельфа "Баренцево море, Юг", который простирается до $74^{\circ} 30^{\prime}$ с.ш., то есть в зону действия Договора о IIIпицбергене.

Это событие, впрочем, не вызвало какой бы то ни было реакции ни внутри страны, ни за рубежом. В предварительном порядке весь шельф архипелага поделен норвежцами на крупные участки. Объем проводимых государством сейсмосъемочных работ на шельфе севернее $74^{\circ} 30^{\prime}$ с.ш. резко возрос, что служит явньм признаком повышения прикладного интереса к этим территориям. 


\section{Рњбоохранная зона в аспекте отнопенй Норвегия с EC}

Взаимоотношения Норвегии с Европейским сообществом играют важнейшую роль во внешней, а в последние годы и во внут ренней политике страны. В 1972 году правительство Норвегии подписало договор о вступлении страны в ЕС, однако на последующем референдуме он не был ратифицирован (с незначитељьым перевесом). Правительство тогда подало в отставку, и на протяжении полутора десятилетий ни одна из политических партий Норвегии не рисковала вновь поднимать этот вопрос, хотя экономическое и научно-техническое сотрудничество с Сообществом развивалось достаточно успешно. Страны ЕС - основные торговые партнеры Норвегии, на них приходится около 60\% товарооборота страны, в том qисле примерно такая же доля экспорта рыбы и продуктов ее переработки.

Торговля рыбой и рыбопродуктами между Норвегией и ЕС регулируется обменньми письмами 1973 года. Они предоставляют Норвегии некоторые таможенные преференции, хотя ряд важных для страны рыбопродуктов при ввозе в страны ЕС по-прежнему облагается высокими (15-20\%) пошлинами. После объявления Норвегией и ЕС 200-мильных экономзон было подписано соглашение о рыболовстве, вступившее в силу в 1981 году. На его основе ежегодно проводятся переговоры между Норвегией и ЕС о предоставлении друг другу квот вылова рыбы в своих зонах.

Разногласия с ЕС в связи с рыбоохранной зоной вокруг ШПпицбергена впервые возникли в ходе конфликта с Испанией в 1986 году. Учитывая, что остальные страны Сообщества подчинились требованию о прекращении промысла, Норвегия пыталась побудить Брюссель оказать соответству́ющее давление и на Испанию. Успеха это не имело: министр иностранных дел Дании У. Эллеманн Йенсен заявил на встрече со своим норвежским коллегой, что это сугубо двусторонний вопрос и он должен решаться без обращения к Комиссии Европейских сообществ (КЕС) ${ }^{22}$.

В середине 80-x годов другие страны EC, лишившиеся доступа $\kappa$ ресурсам канадского побережья, также возобновили интерес к рыбоохранной зоне. На переговорах по квотам на 1987 год Сообщество со ссылкой на Парижский договор оспорило право Норвегии на одностороннее установление квот в районе ІІпицбергена. У норвежской стороны это вызвало определенное беспокойство. В ходе упомянутых переговоров она подчеркнула, что "предоставление EC прав на рыбный промысел в экономической зоне Норвегии предусматривает сдержанность ЕС в вопросе о промысле в рыбоохранной зоне вокруг ІІпицбергена"23. Установка не допускать расширения чьей-либо деятельности в зоне сохраняется, очевидно, и по сей день. 
Это рельефно проявилось в ходе гренландского "вторжения" в рыбоохранную зону в 1991 году. Оно пришлось на период переговоров ЕС с Европейской ассоциацией свобоцной торговли (ЕАCT) о создании единой интеграџионной зоны, где обеспечивались бы "четыре свободы передвижения": товаров, услуг, капитала и рабочей силы. Инициатором создания такой зоны, именуемой Европейским экономическим пространством (ЕЭП), выступила в 1988 году премъерминистр Норвегии Гру Харлем Брундтланд. Таким образом она пыталась обеспечить участие страны в формировании единого европейского рынка, не поднимая политически взрывоопасного вопроса о вступлении страны в ЕС.

Так как страны ЕАСТ были экономически гораздо более заинтересованы в успехе переговоров, а норвежское правительство связало с ними и свой политический престиж, для ЕС были сделаны многочисленные серьезные уступки. К лету 1991 года в деле создания ЕЭП осталось три принципиальных неурегулированных вопроса, едва ли не важнейшим из которых было рыболовство. ЕС требовало увеличения квот в норвежских водах, Норвегия - расширения допуска своих рыбопродуктов на рынок Сообщества. На этом фоне поведекие Гренландии, тесно координирующей свою рыболовную политику с EC и опирающейся на явное одобрение Дании, было расценено как своего рода проверка твердости норвежской позиции по вопросу о рыбоохранной зоне. Как отмечал бывший заместитель министра рыболовства Норвегии И. Кристофферсен, в результате компромиссного соглашения 1991 года гренландцам, по существу, дали отступного, чтобы те в период переговоров по ЕЭП не привлекали внимания к щекотливой для Норвегии проблеме ${ }^{24}$.

В июне 1992 года в Люксембурге был парафирован текст Соглашения по ЕЭI, согласно которому всю квоту ЕС в рыбоохранной зоне вокруг IIпицбергена получали Испания и Португалия. Остальные страны (Дания, Великобритания, Франция и Германия) получали за это компенсационную квоту в экономзоне Норвегии севернее $62^{\circ}$ с.ш. в обмен на предоставление равной квоты норвежским рыбакам в зоне $\mathrm{EC}^{25}$. В сентябре-октябре того же года под давлением ЕС соглашение было пересмотрено в сторону дополнительного увеличения квот Сообщества. Ожидается, что этот прирост передадут Испании и Португалии. Ставки пошлин на норвежские рыбу и рыбопродукты будут в период до 1997 года снижены в среднем на $70 \%$.

Рыбоохранная зона вокруг ІІпицбергена в соглашении не упоминалась. Первоначальное решение данной проблемы было сохранено в силе (равно как и при дополнительном пересмотре некоторых положений соглашения в начале 1993 г. в связи с его нератификаџией в ІІвейцарии). Таким образом, пока Норвегии удалось не допустить 
расширения рыболовной активности ЕС в зоне. Страна продемонстрировала свою политическую заинтересованность в этом, включая готовность идти на определенные уступки в собственной экономической зоне.

Норвежские "европеисты", однако, с самого начала рассматривали ЕЭП лишь как "промежуточную станцию на пути в ЕС". Действитељьо, в конце 1992 года Норвегия подала официальную заявку на вступление в Сообщество. Стране предстоят кропотливые и трудные переговоры об условиях такого вступления, в том числе о переходном периоде для адаптации к единому рынку. Переговоры по ЕЭП наглядно продемонстрировали, что одним из наиболее сложных вопросов станет регулирование рыболовного промысла и рыбной торговли. На Норвегию, безусловно, будет оказано мощное давление со стороны ЕС с целью получения возможно более скорого и широкого доступа к рыбным ресурсам страны. Можно ожидать, что норвежская сторона пойдет здесь на достаточно серьезные уступки в обмен на встречные шаги ЕС в других областях. Политическое влияние норвежских рыбаков, хотя и весьма существенное, все же явно уступает влиянию проевропейского промышленного и судовладельческого лобби.

После вступления Норвегии в ЕС квоты вылова в норвежских зонах будут устанавливатъся Комиссией Европейских сообществ. В экономическом плане это, безусловно, будет означать расширение промысла судами Ислании, Дании, ФРГ и других заинтересованных государств. Именно поэтому прогив членства в ЕС резко выступают норвежские рыбаки (особенно на севере страны).

Членство Норвегии в ЕС имеет ряд сложных юридических моментов. Нељзя исключать того, что вместе с ресурсами рыбоохранной зоны вокруг ШІпицбергена к КЕС "по наследству" перейдут и проблемы взаимоотношений страны с Россией, а далее, возможно, и другими странами Восточной Европы. Вместе с тем сама юрисдикция КЕС В зоне Шпицбергена представляется спорной, поскольку ЕС как субъект международного права нв является участником Договора о Шпицбергене. Во избежание юридических коллизий известная северонорвежская консультативная фирма "Барлиндхауг" даже рекомендовала в принщипе исключить зону ІІпицбергена из заявки на вступление Норвегии в $\mathrm{EC}^{26}$.

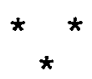

Рыбоохранная зона вокруг IІпицбергена - политически важная для Норвегии морская территория с уникальным правовым статусом. 
В первую очередь он определяется характерными особенностями самого архипелага. Обтекаемые, не всегда четкие формулировки Договора о ІІпицбергене, широкие права его участников создают основу для различных толкований. При этом ни одно из них не может получить международной поддержки, если односторонне ущемляет интересы какой-либо страны- участницы договора.

Норвежцы полностью осознают юридические и политические сложности ситуации, поэтому, твердо отстаивая свою позицию на словах, они избегают применения силовых методов, чтобы не обострять ее. В то же время рыбацкие и экологические организации все в большей степени оказывают на правительтво нажим с цељю проведения более решительной и действенной политики. Вполне возможно, что под их воздействием норвежские власти постепенно ужесточат позицию, тем более что она может оказать влияние и на условия вступления Норвегия в ЕС, а также на решение вопроса о шельфе Шпицбергена.

Политика стран в отношении рыбоохранной зоны определяется прежде всего их реальньми и потенциальными экономическими интересами в зоне архипелага. Чем больше эта заинтересованность, тем слабее подцержка норвежской точки зрения и тем активнее защита собственных прав по Парижскому договору.

На этом фоне негативная позиция бывшего СССР представляется вполне объяснимой, особенно с учетом наличия у страны не только хозяйственных, но и серьезных военно-стратегических интересов в Баренцевом море. В целом Россию, очевидно, устроило бы сохранение в зоне IIпицбергена status quo. Это, с одной стороны, желательный для нас низкий уровень напряженности в зоне, с другой - сохранение за нами достаточно широкой свобошы действий как в экономическом, так и в политическом плане.

Представляется целесообразным дапьнйшее активное развитие практического сотрудничества с Норвегией и другими странами в деле улушшения ресурсной ситуащии Баренщева моря, включая район IIпицбергена. Следует также внимательно отслеживать изменения в политических позициях Норвегии и третъих стран, в особенности Испании и Португалии. Как оппоненты Норвегии в данном вопросе, они выступают в роли наших естественных союзников. В то же время как новые члены ЕC, они особенно активно вовлекают проблематику рыбоохранной зоны и вообще рыболовства в переговоры между Осло и Брюсселем, и поэтому важно постоянно знать их точку зрения на этот счет. 
Перспектива вступления Норвегии в ЕС может различным образом отразиться на статусе рыбоохранной зоны. Все будет определяться теми правами, которые получит по отношению к зоне Комиссия Европейских сообществ. В случае, если вопрос о компенсации ЕС в рыбоохранной зоне не будет должным образом урегулирован, можно ожидать, что status quo в целом сохранится. Третьи страны (Испания, Португалия и др.) будут и далее, подобно России, оспаривать статус зоны на уровне двусторонних отношений, хотя уже и в рамках ЕС. Если же на рыбоохранную зону однозначно распространится компетенция КЕС (что представляется более вероятным), то России, очевидно, придется отстаивать свои рыболовные интересы в ней уже перед объединенными силами Сообщества. В этой связи наша последовательная приверженность принципу равного права на промысел в водах IIпицбергена (теперь уже и со ссылкой на имеющуюся практику) приобретает особое значение.

1 CM. Svalbard: Samling av lorer, forskrifter og bestemmelser. - Oslo, 1986. S. $123-124$.

2 Barentshavets ressurser. - Trondheim, 1986. - S. 55. C. $1-9$.

3 См. Сводка правовьг докумевтов о Мпищбергеве. - Осло, 1988. -

4 CM. St meld - 1974-75. - Nr. 39. - Vedrorende Svalbard. - S. 7.

5 Ibid. - 1985-1986. - Nr. 40. - Svalbard. - S. 9.

6 Мехдународная хинаны. - 1988. - No 7. - C. 20.

7 См. Нсторня Норвегін/Oтв. ред. А.С. Кан. - М., 1980. - С. 564, 572-573.

8 Churcill R. The Soviet Union and Jurisdictional Disputes in Northern Waters// The Soviet Union and Northern Waters/Ed. by C. Archer. - L., 1989. - P. 56.

9 CM. Grytas G., Skoglund T. Kystfolket og ressursene - semarbeid eller isolasjon i 80-ara. - Oslo, 1982. - S. 82-84.

10 Сборник руководяших докумевтов по рњболовству в 200-мдльной зковомптеской зове Норветпи, 200-мониой рьболовной зоне острова Ян-Майев,

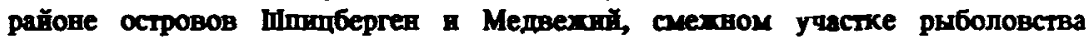
"СССР - Норветия" в морсиих районах Баренщева моря, притеганпих $\mathrm{k}$ поберехор CCCP. - Мурманск, 1982.

11 C. Ulfstein G. Fra 12 til 200 mils ressurskrise?//Kan fiskerinaeringa styres?//B. Hersoug (red.). - Oslo, 1983. - S. 84.

12 CM. Schram Stokke O., Hoel A.H. A Bridge over Troubled Waters: International Fisheries Management in the Barents Sea. - Oslo, 1990. - P. 5.

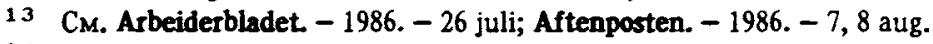

14 CM. Aftenposten. - 1986. - 13,14 aug.; Dagbladet - 1986. - 14 aug.; Nordlys. $-1986 .-14$ aug.

15 C $_{M}$. Nordlys. - 1988. $-25,26,31$ aug., 7 sept.

16 Nordlys. $-1991 .-17$ sept.

17 CM. Nordlys. - 1991. - 16 mai, 3, 4 juli, 25, 26 sept.; Fiskaren. 1991. - 27 sept. 
18 CM. Aftenposten. - 1991. - 19 sept.

19 CM. St. forh - 1991-1992. - Nr. 21. - S. 1806-1807.

20 Aftenposten - 1988. - 23 sept.

21 CM. Aftenposten. - 1986. -9 aug.

22 CM. Dagbladet - 1986. -14 aug.

23 St. meld - 1986-1987. - Nr. 61. - Norge, EF og europeisk samarbeid. S. 21.

24 C. Nordlys. - 1991. -26 sept.

25 Dagbladet. - 1992. - 19 juni.

$26 \mathrm{CM}$. Nord-norske utfordringer og forholdet til det framtidige EF: En utre dning for Troms Fylkekommune. - Tromso, 1989. - S. 62-63. 